\title{
Nucleotide sequence, genomic organization and chromosome localization of $5 S$ rDNA in two species of Curimatidae (Teleostei, Characiformes)
}

\author{
Lessandra Viviane De Rosa Santos, Fausto Foresti, Adriane Pinto Wasko, Claudio Oliveira \\ and Cesar Martins \\ UNESP, Universidade Estadual Paulista, Instituto de Biociências, Departamento de Morfologia, \\ Botucatu, SP, Brazil.
}

\begin{abstract}
The $5 S$ ribosomal DNA ( $5 S$ rDNA) of higher eukaryotes is organized in repeat units of tandem arrays composed of a $5 S$ rDNA coding region, conserved even among non-related taxa, and a variable non-transcribed spacer sequence (NTS). To contribute to knowledge on the organization and evolution of vertebrate 5S rDNA we used PCR, nucleotide sequencing, Southern blot hybridization and chromosome fluorescence in situ hybridization (FISH) to investigate 5S rDNA tandem repeats in the South American Curimatidae fish Steindachnerina insculpta and Cyphocharax modesta. 5S rDNA repeats of 180 base pairs (bp) from both species were PCR-generated and sequenced evidencing the shortest $5 \mathrm{~S}$ rDNA monomer so far described in eukaryote species. Southern blotting revealed that both species contained two tandem 5S rDNA classes, the PCR amplified fragment composed of 180 bp monomers and a class of $1600 \mathrm{bp}$ monomers not detected by PCR. Chromosome mapping of the 5S rDNA repeats identified a major locus in both species and a second minor locus only in C. modesta. The Southern blot and chromosome mapping data indicate the presence of different types of 5S rDNA tandem repeats in the Curimatidae genome.
\end{abstract}

Key words: Cyphocharax modesta, Steindachnerina insculpta, 5S rDNA, chromosomes, FISH, nucleotide sequence.

Received: May 24, 2005; Accepted: July 26, 2005.

\section{Introduction}

Studies of ribosomal RNA genes have gained prominence in a broad range of animals and plants, especially for the identification of species and specific populations, the study of evolutionary relationships and the characterization of genome structure. The 5S ribosomal DNA (5S rDNA) array consists of multiple copies of a highly conserved 120 base pair (bp) coding sequence, separated by a variable non-transcribed spacer (NTS) (e.g. Long and David, 1980). While the 5S rRNA gene is conserved even among nonrelated taxa, the NTS shows extensive length and sequence variation, which can give accentuated dynamism to these genes (Williams and Strobeck, 1985).

Variations in the NTS of the $5 \mathrm{~S}$ rDNA owing to insertions/deletions, minirepeats and pseudogenes have been useful for evolutionary studies and served as species- or population-specific markers for various organisms, including plants (Solanum tuberosum and Solanum pinnatisectum) (Zanke et al., 1995), mammals (Mus

Send correspondence to Cesar Martins. UNESP, Universidade Estadual Paulista, Instituto de Biociências, Departamento de Morfologia, 18618-000 Botucatu, SP, Brazil. E-mail: cmartins@ibb. unesp.br. musculus domesticus and Mus musculus musculus) (Suzuki et al., 1994) and fish (Oncorhynchus mykiss, Salmo salar, Salmo truta, Brama raii, Solea solea, Reinhardtius hippoglossoides, Anguilla anguilla, Anguilla rostrata and Oreochromis niloticus) (Pendás et al., 1995, Nieddu et al., 1998, Céspedes et al., 1999, Carrera et al., 2000; Martins et al., 2002). Variations in the 5S rDNA non-transcribed spacer have also been detected in some Neotropical fish such as Leporinus (Martins and Galetti, 2001a) and Brycon (Wasko et al., 2001) species. Fish 5S rDNA repeat structure data suggest that the complex genomic organization of these sequences is associated with a high rate of NTS evolution, and it seems that detailed studies of these sequences could provide useful information on the structure and evolution of the 5S rDNA multigene family and contribute to elucidating the organization of the fish genome.

The Curimatidae fish family is composed of eight genera and 97 valid species distributed in river basins throughout South and Central America (Vari, 2003), most of the species studied presenting high karyotypic similarity with a diploid number of 54 metacentric and submetacentric chromosomes (Galetti et al., 1994). The chromosomal stability of this family means that it is often difficult to identify species-specific cytogenetic markers, although 
recent and more discriminating cytogenetic methodologies such as fluorescence in situ hybridization (FISH) to identify specific DNA segments (especially ribosomal DNA) and molecular techniques such as DNA sequencing and Southern blotting offer new approaches to the identification of species- or population-specific markers which can contribute to understanding evolution in the Curimatidae.

The purpose of the study described in this paper was to characterize $5 \mathrm{~S}$ rDNA organization in the Curimatidae species Steindachnerina insculpta and Cyphocharax modesta, in order to better understand the organization and evolution of such repeats in fish genomes.

\section{Material and Methods}

\section{Fish specimens.}

Specimens of Steindachnerina insculpta and Cyphocharax modesta were collected in the Paranapanema river (5 male and 1 female $S$. insculpta and 18 male and 9 female $C$. modesta) and Tietê river ( 5 male and 12 female $S$. insculpta and 3 male and 9 female C. modesta) in the Brazilian state of São Paulo. Voucher specimens were deposited in the Fish Biology and Genetics Laboratory collection at UNESP (Laboratório de Biologia e Genética de Peixes (LBP) Instituto de Biociências, Botucatu, Brazil).

\section{DNA samples, PCR, Cloning, sequencing and sequence analyses}

Genomic DNA was extracted from liver tissue of the fish using the phenol-chloroform method (Sambrook and Russel, 2001) and PCR amplification of 5S rDNA was carried out as described in Martins and Galetti (2001a) using the 5SA primer 5'-TAC GCC CGA TCT CGT CCG ATC-3' (corresponding to nucleotides $24-44$ of the $5 \mathrm{~S}$ coding region) and the $5 \mathrm{SB}$ primer 5'-CAG GCT GGT ATG GCC GTA AGC-3' (nucleotides $01-21$ of the 5S region) designed to amplify $118 \mathrm{bp}$ of the 5S rRNA gene and the complete NTS. The PCR-amplified products of five specimens of each species were cloned in the pGEM-T plasmid (Promega) and used to transform competent E. coli strain DH5 $\alpha$ cells. Positive clones for $5 \mathrm{~S}$ rDNA were sequenced on an ABI Prism 377 DNA Sequencer (Applied Biosystems) using the DYEnamic Terminator Cycle Sequencing kit (Amersham Pharmacia Biotech). The alignment of the sequences was performed using Clustal $\mathrm{W}$ (Thompson et al., 1994) and the nucleic acid sequences were subjected to Blast n (Altschul et al., 1990) searches at the National Center for Biotechnology Information website (http://www. ncbi.nlm.nih.gov/blast).

\section{Southern blot hybridization}

The genomic organization of the $5 \mathrm{~S}$ rDNA was determined by Southern blot hybridization. Approximately $5 \mu \mathrm{g}$ of genomic DNA were digested with HindIII for 10 minutes ( $S$. insculpta and C. modesta) or overnight $(C$. modesta). After digestion the products were separated by electrophoresis on $1 \%(\mathrm{w} / \mathrm{v})$ agarose gel, transferred to a Hybond-N nylon membrane (Sambrook and Russel, 2001) and hybridized with the $C$. modesta $5 \mathrm{~S}$ rDNA obtained by PCR (q.v. above), which was labeled and detected using the ECL-Direct Nucleic Acid Labeling and Detection System (Amersham Pharmacia Biotech).

\section{Chromosome preparation and fluorescence in situ hybridization (FISH)}

Mitotic chromosomes were prepared from anterior kidney cells with in vivo colchicine treatment (Bertollo et al., 1978). FISH was performed as described by Pinkel et al. (1986) with modifications (Martins and Galetti, 1999), using a PCR-generated 5S rDNA sequence of Cyphocharax modesta that was labeled by nick translation with biotin-dATP (Bionick $^{\text {TM }}$ Labeling System-Gibco. BRL).

\section{Results and Discussion}

Polymerase chain reaction amplification of the $5 \mathrm{~S}$ rDNA of Steindachnerina insculpta and Cyphocharax modesta generated a single band of approximately $200 \mathrm{bp}$ on agarose gel electrophoresis. Sequencing analyses showed 5S rDNA arrays of $180 \mathrm{bp}$, and the alignment of the sequences enabled the identification of $118 \mathrm{bp}$ of the $5 \mathrm{~S}$ rRNA gene and the whole NTS with 62 bp (Figure 1).

A 62 bp NTS seems to be a common character in Curimatidae because it has also been described in Steindachnerina elegans, another species of the group (Martins and Galetti, 2001b). Research on a variety of organism (Martins and Wasko, 2004) has shown that the shortest 5S rDNA NTS sequence so far described in eukaryotes is $62 \mathrm{bp}$ and various authors (Nederby-Nielsen et al., 1993; Suzuki et al., 1996; Hallenberg and Frederiksen, 2001) have shown that conserved elements inside NTS regions can play an important role in the regulation of 5S rRNA expression. Short NTS sequences, as detected by in S. insculpta and C. modesta, could represent the shortest sequence length necessary for the genomic organization and activity of the 5S rRNA genes.

We detected a highly conserved region corresponding to the $5 \mathrm{~S}$ rRNA gene with an average sequence identity of $98.5 \%$ among our sequenced clones. Searches using the Blastn program at NCBI (Altschul et al., 1990) detected low divergence between the 5S rRNA gene sequences of $S$. insculpta and C. modesta specimens and many other vertebrates, including other fish species. However, the 5S rDNA NTS regions of $C$. modesta and $S$. insculpta were more variable, with an average sequence similarity of $93 \%$ among the clones analyzed, and no sequence correspondence was seen between the NTS regions of S. insculpta and $C$. modesta samples and those of other fish, indicating that this spacer region evolves rapidly. Presumably, NTS regions are free to vary because they are not under strong 


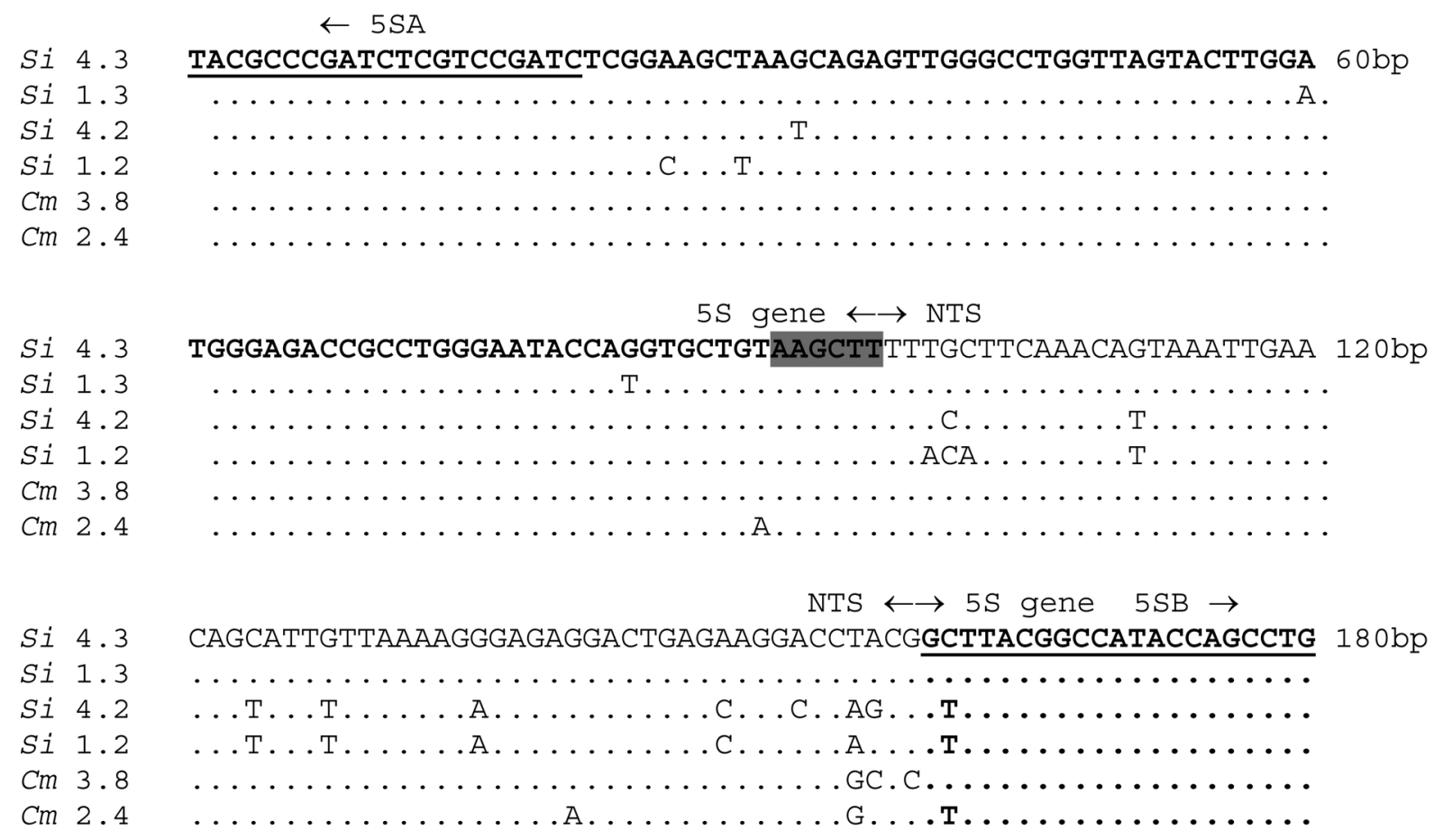

Figure 1 - Alignment of 5S rDNA sequences of Steidachnerina insculpta $(\mathrm{Si})$, and Cyphocharax modesta $(\mathrm{Cm})$. The coding sequence of the $5 \mathrm{~S}$ rDNA is in bold and the boundaries of the 5S rRNA gene and the NTS are also indicated. Primers 5SA and 5SB used to obtain the sequences are underlined and an arrowhead indicates the amplification direction. The HindIII restriction site (AAGCTT) is shown in gray shadowing.

selective pressure, while most 5S rRNA gene mutations are selectively neutral or nearly neutral only when they occur in a subcritical proportion (Cronn et al., 1996).

Several plant and animal species show 5S rDNA polymorphisms related to variations in their NTS regions, and these have been useful as genetic markers to distinguish closely-related species, subspecies, lines and hybrids (Pendás et al., 1995) and also in evolutionary analyses (Crisp et al., 1999). Related fish species generally show $5 \mathrm{~S}$ rDNA species-specific sequences such as those detected in the piscine genera Brycon (Wasko et al., 2001) and Leporinus (Martins and Galetti, 2001a). However, due to the high nucleotide similarity of our specimens we were unable to differentiate between the 5S rDNA sequence of $S$. insculpta and C. modesta (Figure 1).

Partial HindIII restriction enzyme digestion of the genomic DNA of $S$. insculpta and C. modesta produced $180 \mathrm{bp} 5 \mathrm{~S} \mathrm{rDNA}$ monomer bands (Figure 2), indicating that the $5 \mathrm{~S}$ rDNA of both species is organized in tandem-arrays. In both $S$. insculpta and C. modesta PCR cloning and sequence analyses detected only one $5 \mathrm{~S}$ rDNA repeat class while Southern blotting showed two distinct 5S rDNA repeat classes consisting of a $180 \mathrm{bp}$ repeat, quite similar in both species (Figures 1 and 2), and a repeat of about 1600 bp which was slightly longer in $S$. insculpta than in $C$. modesta, possibly due to differences in the number of nucleotide bases within the 5S rDNA NTS region (Figure 2). Variant 5S rDNA repeat classes within a single genome have been identified in several piscine species, including
Salmo salar (Pendás et al., 1994), Oncorhynchus mykiss (Morán et al., 1996), Coregonus (Sajdak et al., 1998), Brycon (Wasko et al., 2001) and Oreochromis niloticus (Martins et al., 2002) and seem to be a general trend in this vertebrate group (Martins and Galetti, 2001b).

The two 5S rDNA repeat classes of $180 \mathrm{bp}$ and $1600 \mathrm{bp}$ identified in S. insculpta and C. modesta can be compared to the dual 5S rDNA system found in Anostomidae species - 5S monomers with $200 \mathrm{bp}$ and $900 \mathrm{bp}$ have been described for several species of Leporinus (Martins and Galetti, 2001a). The 200 bp 5S rDNA monomer of Leporinus also presents a NTS composed by a small number of nucleotides, representing one of the shortest NTSs so far described in eukaryote species.

Previous cytogenetic studies have shown that the karyotype of S. insculpta and C. modesta consists of 54 metacentric and submetacentric chromosomes (Venere and Galetti, 1989). In our study, 5S rDNA FISH revealed bright signals on the pericentromeric region of the short arms of a single chromosome pair of both $S$. insculpta and $C$. modesta (Figure 3) that seems to be homologous between the two species. We also observed two additional weak fluorescence signals in the pericentromeric region of a second chromosome pair of a few C. modesta metaphases (Figure 3 detail), indicating the presence of a major and a minor $5 \mathrm{~S}$ cluster in this species. No weak fluorescent signals were seen in S. insculpta, but the existence of few copies of a second 5S rDNA locus in S. insculpta cannot be ruled out since such copies may not have been detected by the hybridiza- 
tion conditions employed in our experiments. The two $5 \mathrm{~S}$ classes - $180 \mathrm{bp}$ and $1600 \mathrm{bp}$ - identified in Curimatidae might be related to the major and minor $5 \mathrm{~S}$ rDNA chromosome loci as demonstrated in Leporinus. The two 5S rDNA monomers with $200 \mathrm{bp}$ and $900 \mathrm{bp}$ described for several species of Leporinus map to different chromosome loci (Martins and Galetti, 2001a).

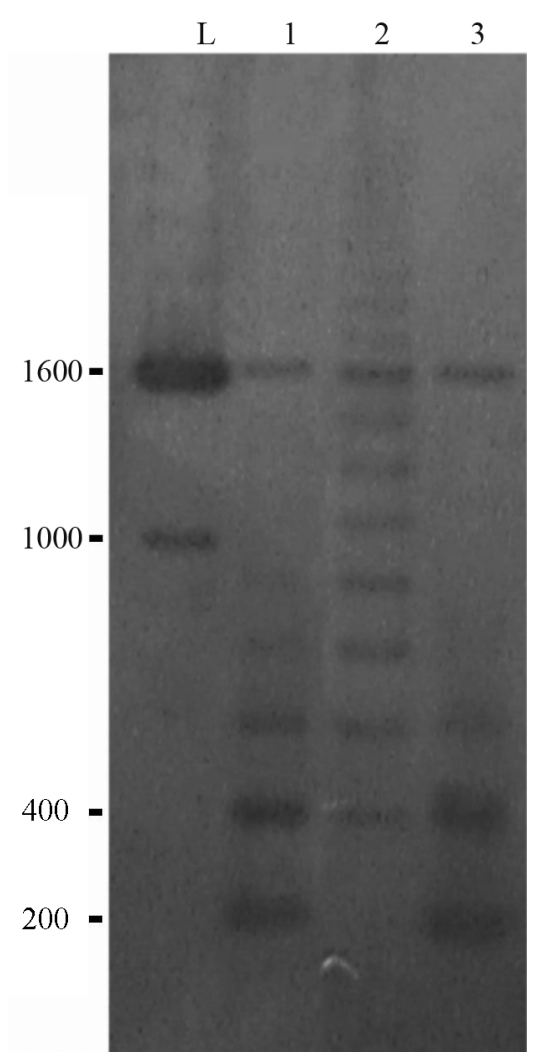

Figure 2 - Southern blot hybridization of HindIII-digested genomic DNA of Steindachnerina insculpta (1) and Cyphocharax modesta (2 and 3), using a $5 \mathrm{~S} \mathrm{rDNA}$ monomer as a probe. DNA was digested for $10 \mathrm{~min}$ in 1 and 2 and overnight in 3 . Molecular weight markers (bp) are indicated on the left.
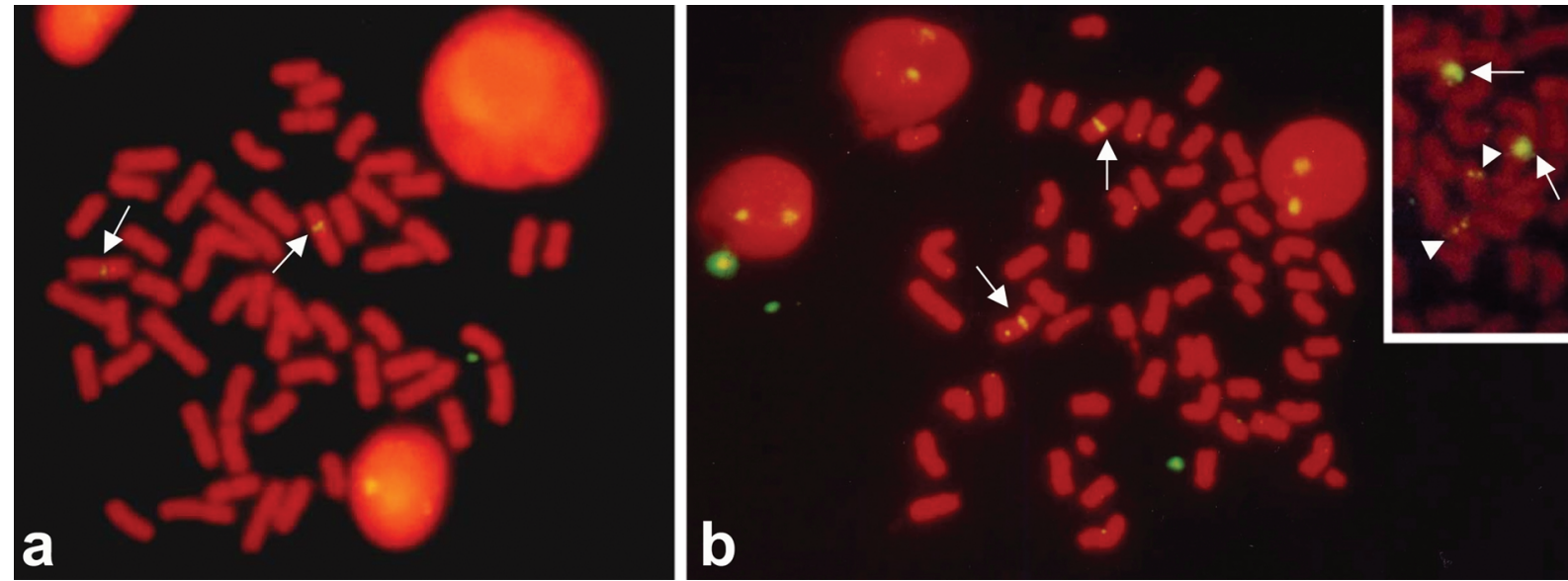

Figure 3 - 5S rDNA fluorescence in situ hybridization of metaphase chromosome spreads of (a) Steindachnerina insculpta and (b) Cyphocharax modesta. A single $5 \mathrm{~S}$ rDNA locus is shown in a and b (arrows). In the detail, minor $5 \mathrm{~S}$ rDNA loci (arrowheads) that were also observed in $C$. modesta.
In fact, similar major and minor 5S rDNA repeats, which seem to be on homologous chromosomes, have been described in several Leporinus and Schizodon (Anostomidae) species (Martins and Galetti, 1999, 2000, 2001a), in Parodon (Parodontidae) (Vicente et al., 2001) and Prochilodus argenteus (Prochilodontidae) (Hatanaka and Galetti, 2004). A phylogenetic interpretation based on morphological traits has shown that Curimatidae, Prochilodontidae, Anostomidae and Chilodontidae constitute a major monophyletic unit of Characiformes composed of two sister clades, one comprising the Curimatidae and Prochilodontidae and the other Anostomidae and Chilodontidae (Vari, 1983). The chromosome distribution of the 5S rDNA in these families is in accordance with the grouping of these four families hypothesis, however, we found no similarity between the curimatid 5S rDNA nucleotide sequences identified by us and anostomid sequences from Leporinus species available at the GenBank. Although the chromosome structure of the $5 \mathrm{~S}$ rDNA clusters of these families seems to have been preserved from major changes during evolution, their nucleotide sequence seems to be evolving fast.

Martins and Wasko (2004) have pointed out that in piscines the 5S rDNA repeat clusters are most commonly located at interstitial chromosome sites, and this has also been reported for mammals (Mellink et al., 1996; Frederiksen et al., 1997; Mäkinem et al., 1997) and amphibians (Vitelli et al., 1982; Schmid et al., 1987; Lucchini et al., 1993), suggesting that such distribution could represent some advantage related to the organization of these genes in the vertebrate genome (Martins and Galetti, 1999). It is interesting to note that even in other piscine species with high rates of chromosome variations such as the genus Astyanax (Characidae), the 5S rDNA chromosome clusters are conserved among species (Almeida-Toledo et al., 2002; Mantovani et al., 2005). Alternatively, the 5S rDNA clusters could be organized in a major linked group with the presence of other important genes and disruptive interfer- 
ence in such region would be under strong selective pressure.

\section{Acknowledgments}

The authors thank Fernanda A. Alves and Fábio E. Severino for helpful assistance. L.V.R.S. was supported by a fellowship from Coordenação de Aperfeiçoamento de Pessoal de Nível Superior (CAPES). This work was also supported by grants from the Brazilian agencies Conselho Nacional de Desenvolvimento Científico e Tecnológico (CNPq), and Fundação de Amparo à Pesquisa do Estado de São Paulo (FAPESP).

\section{References}

Almeida-Toledo LF, Ozouf-Costaz C, Foresti F, Bonillo C, Porto-Foresti F and Daniel-Silva MFZ (2002) Conservation of the $5 \mathrm{~S}$ bearing chromosome pair and co-localization with major rDNA clusters in five species of Astyanax (Pisces, Characidae). Cytogenet Genome Res 97:229-233.

Altschul SF, Gish W, Miller W, Myers EW and Lipman DJ (1990) Basic local alignment search tool. J Mol Biol 215:403-410.

Bertollo LAC, Takahashi CS and Moreira-Filho O (1978) Karyotypic studies of two allopatric populations of the genus Hoplias (Pisces, Erythrinidae). Braz J Genet 2:17-37.

Carrera E, Garcia T, Céspedes A, Gonzáles I, Fernandez A, Asensio LM, Hernandez PE and Mantin R (2000). Differentiation of smoked Salmo salar, Oncorhynchus mykiss and Brama raii using the nucleolar marker $5 \mathrm{~S}$ rDNA. Int J Food Sci Tech 35:401-406.

Céspedes A, Garcia T, Carrera E, Gonzalez I, Fernandez A, Hernández PE and Martin R (1999) Identification of sole (Solea solea) and greenlanda halibut (Reinhadtius hippoglossoides) by PCR amplification of the 5S rDNA gene. J Agric Food Chem 47:1046-1050.

Crisp MD, Appels R, Smith FM and Keys WMS (1999) Phylogenetic evaluation of $5 \mathrm{~S}$ ribosomal RNA gene and spacer in the Callistachys group (Fabacea, Mirbelieae). Plant Syst Evol 218:33-42.

Cronn RC, Zhao X, Paterson AH and Wendel JF (1996) Polymorphism and concerted evolution in a tandemly repeated gene family: $5 \mathrm{~S}$ ribosomal DNA in diploid and allopolyploid cottons. J Mol Evol 42:685-705.

Frederiksen S, Cao H, Lomholt B, Levan G and Hallemberg C (1997) The rat 5S rDNA bona fide gene repeat maps to chromosome $19 \mathrm{q} 12$ qter and the pseudogene repeat maps to 12q12. Cytogenet Cell Genet 76:101-106.

Galetti Jr PM, Bertollo LAC and Moreira Filho O (1994) Trends in chromosome evolution of neotropical characiform fishes. Caryologia 47:289-298.

Hallenberg C and Frederiksen S (2001) Effect of mutations in the upstream promoter on the transcription of human $5 \mathrm{~S}$ rRNA genes. Biochim Biophys Acta 2:169-73.

Hatanaka T and Galetti Jr PM (2004) Mapping of the 18S and 5S ribosomal RNA genes in the fish Prochilodus argenteus Agassiz, 1829 (Characiformes, Prochilodontidae). Genetica 122:239-244.

Long EO and David ID (1980) Repeated genes in eukaryotes. Ann Rev Biochem 49:727-764.
Lucchini S, Nardi I, Barsacchi G, Batistoni R and Andronico F (1993) Molecular cytogenetics of the ribosomal (18S + 28S and 5S) DNA loci in primitive and advanced urodele amphibians. Genome 36:762-773.

Mäkinem A, Zijlstra C, De Haan NA, Mellink CHM and Bosma AA (1997) Localization of $18 \mathrm{~S}$ plus $28 \mathrm{~S}$ and $5 \mathrm{~S}$ ribosomal RNA genes in the dog by fluorescence in situ hybridization. Cytogenet Cell Genet 78:231-235.

Mantovani M, Abel LDS and Moreira-Filho O (2005) Conserved $5 \mathrm{~S}$ and variable $45 \mathrm{~S}$ rDNA chromosomal localization revealed by FISH in Astyanax scabripinnis (Pisces, Characidae). Genetica 123:211-216.

Martins C and Galetti Jr PM (1999) Chromosomal localization of 5S rDNA genes in Leporinus fish (Anostomidae, Characiformes). Chromosome Res 7:363-367.

Martins C and Galetti Jr PM (2000) Conservative distribution of 5S rDNA loci in Schizodon (Pisces, Anostomidae) chromosomes. Chromosome Res 8:353-355.

Martins C and Galetti Jr PM (2001a). Organization of 5S rDNA in species of the fish Leporinus: Two different genomic locations are characterized by distinct nontranscribed spacers. Genome 44:903-910.

Martins C and Galetti Jr PM (2001b) Two 5S rDNA arrays in Neotropical fish species: Is it a general rule for fishes? Genetica 111:439-446.

Martins C, Wasko AP, Oliveira C, Porto-Foresti F, Parise-Maltempi P, Wright JM and Foresti F (2002) Dynamics of 5S rDNA in the tilapia (Oreochromis niloticus) genome: Repeat units, inverted sequences, pseudogenes and chromosome loci. Cytogenet Genome Res 98:78-85.

Martins C and Wasko AP (2004) Organization and evolution of $5 \mathrm{~S}$ ribosomal DNA in the fish genome. In: CR Williams (ed) Focus on Genome Research. Nova Science Publishers, Hauppauge, pp 289-319.

Mellink CHM, Bosma AA, Haan NA and Zijlstra C (1996) Physical localization of 5S rRNA genes in the pig by fluorescence in situ hybridization. Hereditas 124:95-97.

Morán P, Martínez JL, Garcia-Vásquez E and Pendás AM (1996) Sex chromosome linkage of $5 \mathrm{~S}$ rDNA in rainbow trout (Oncorhynchus mykiss). Cytogenet Cell Genet 75:145-150.

Nederby-Nielsen J, Hallenberg C, Frederiksen S, Sorensen PD and Lomholt B (1993). Trancription of human 5S rRNA genes is influenced by an upstream DNA sequence. Nucleic Acids Res 26:3631-3636.

Nieddu M, Pichiri G, Coni P, Salvadori S, Deiana AM and Mezzanote R (1998) A comparative analysis of European and American eel (Anguilla anguilla and Anguilla rostrata) genomic DNA: 5S rDNA polymorphism permits the distinction between the two populations. Genome 41:728-732.

Pendás AM, Morán P, Freije JP and Garcia-Vásquez E (1994) Chromosomal location and nucleotide sequence of two tandem repeats of the Atlantic salmon 5S rDNA. Cytogenet Cell Genet 67:31-36.

Pendás AM, Móran P, Martínez JL and Garcia-Vásquez E (1995) Applications of 5S rDNA in Atlantic salmon, brow trout, and in Atlantic salmon $\mathrm{x}$ brown trout hybrid identification. Mol Ecol 4:275-276.

Pinkel D, Straume T and Gray JW (1986) Cytogenetic analysis using quantitative, high-sensitivity, fluorescence hybridization. Proc Nat Acad Sci USA 83:2934-2938. 
Sajdak SL, Reed KM and Phillips RB (1998) Intraindividual and interspecies variation in the $5 \mathrm{~S}$ rDNA of coregonid fish. $\mathrm{J}$ Mol Evol 46:680-688.

Sambrook J and Russell DW (2001) Molecular Cloning: A Laboratory Manual. Cold Spring Harbor Laboratory Press, Cold Spring Harbor, New York.

Schmid M, Vitelli L and Batistoni R (1987) Chromosome banding in Amphibia. IV. Constitutive heterochromatin, nucleolus organizers, $18 \mathrm{~S}+28 \mathrm{~S}$ and $5 \mathrm{~S}$ ribosomal RNA genes in Ascaphidae, Pipidae, Discoglossidae and Pelobatidae. Chromosoma 95:271-284.

Suzuki H, Moriwaki K and Sakurai S (1994) Sequences and evolutionary analysis of mouse 5S rDNAs. Mol Biol Evol 11:704-710.

Suzuki H, Sakurai S and Matsuda Y (1996) Rat rDNA spacer sequences and chromosomal assignment of the genes to the extreme terminal region of chromosome 19. Cytogenet Cell Genet 72:1-4.

Thompson JD, Higgins DG and Gibson TJ (1994) Clustal W: Improving the sensitivity of progressive multiple sequence alignment through sequence weighting, position-specific gap penalties and weight matrix choice. Nucleic Acids Res 22:4673-4680.

Vari RP (1983) Phylogenetic relationships of the families Curimatidae, Prochilodontidae, Anostomidae and Chilodontidae (Pisces, Characiformes). Smithsonian Contributions to Zoology 378:1-59.
Vari RP (2003) Curimatidae. In: RE Reis, SO Kullander and CJ Ferraris (eds) Check List of the Freshwater Fishes of South America. Edipucrs, Porto Alegre, pp 51-64.

Venere PC and Galetti Jr PM (1989) Chromosome evolution and phylogenetic relationships of some Neotropical Characiformes of the family Curimatidae. Braz J Genet 12:1725.

Vicente VE, Jesus CM and Moreira Filho O (2001) Chromosomal localization of $5 \mathrm{~S}$ and $18 \mathrm{~S}$ rRNA genes in three Parodon species (Pisces, Parodontidae). Caryologia 4:365-369.

Vitelli L, Batistoni R, Andronico F, Nardi I and Barsacchi-Pilone $\mathrm{G}$ (1982) Chromosomal localization of $18 \mathrm{~S}+28 \mathrm{~S}$ and $5 \mathrm{~S}$ ribosomal RNA genes in evolutionary divergent anuran amphibians. Chromosoma 84:475-491.

Wasko AP, Martins C, Wright JM and Jr Galetti PM (2001) Molecular organization of $5 \mathrm{~S}$ rDNA in fishes of the genus Brycon. Genome 44:893-902.

Williams SM and Strobeck C (1985) Sister chromatid exchange and the evolution of rDNA spacer length. J Theor Biol 116:625-636.

Zanke C, Borisjuk N, Ruoss B and Schilderentschler L (1995) A specific oligonucleotide of the 5S rDNA spacer and species-specific elements identify symmetrical somatic hybrids between Solanum tuberosum and S. pinnatisectum. Theor Appl Genet 90:720-726.

Associate Editor: Yatiyo Yonenaga-Yassuda 